\section{Moisture Interception as a Factor in the Competitive Ability of Bluebunch Wheatgrass ${ }^{1}$}

\author{
M. S. NDAWULA-SENYIMBA, V. C. BRINK, \\ AND A. MCLEAN
}

Graduate Student ${ }^{2}$ and Professor of Agronomy, Division of Plant Science, University of British Columbia, Vancouver; and Research Scientist, Research Station, Canada Department of Agriculture, Kamloops, B. C.

\section{Highlight}

Aerial parts of the caespitose type of bluebunch wheatgrass (Agropyron spicatum) have been shown to direct rainwater and to concentrate it in the soil immediately beneath individual plants. The degree to which water collects beneath the bunches appeared to be related to the size of the canopy.

It is possible that the rapid decline of bluebunch wheatgrass under heavy grazing is related to soil moisture redistribution caused by the removal of its aerial parts.

Many workers have emphasized the importance of bluebunch wheatgrass (Agropyron spicatum) on the native ranges of western North America and considerable information is available on the response of this species to grazing pressure. In spite of the attention given to the productivity of the wheatgrass, little attention has been paid to the factors which enable the species to dominate wellmanaged ranges.

Several reports have pointed out that bluebunch wheatgrass succumbs easily to heavy grazing and that under such conditions, the species is weakened and its habitat is invaded by annuals, such as cheatgrass (Bromus tectorum L.), and shrubs, such as big sagebrush (Artemisia tridentata Nutt.), (Tisdale, 1947; Ellison, 1960; Harris, 1967; NdawulaSenyimba, 1969). Harris (1967) pointed out that although cheatgrass seedlings often do better in competition with the wheatgrass seedlings, mature plants of the wheatgrass are resistant to the invasion of annual plants.

In East Africa Glover and Gwynnc (1962) and Gwynne (1966) demonstrated that aerial parts of a plant may collect rainwater and deliver it to the soil at the base of the plant. Earlier Glover (1950) had shown that the depth of rainwater pcnetration in the soil under a vegetation cover varied with the species composition of that cover. In 1962 Glover et al. also developed mathematical expressions which attempted to relate the

${ }^{1}$ Received May 15, 1970; accepted for publication July 13, 1970.

${ }^{2}$ Research Officer, East African Agriculture and Forestry Research Organization, Nairobi, Kenya. depth of water penetration to the heights of plants of known species under specific soil conditions. Gwynne (1966) concluded that, in the dry savannahs of East Africa, many plants growing in arid places survive on very light rains by directing the water to their rooting zone.

The question posed by the present work was whether or not a caespitose grass, such as bluebunch wheatgrass, growing in an arid to semi-arid climate in a temperate latitude "collects" rainwater in much the same manner as do the caespitose species of the drylands of East Africa.

\section{Materials and Methods}

Bluebunch wheatgrass is the most important grass on the dry ranges of south-central British Columbia. The grass is perennial and generally caespitose in form, although rhizomatous varieties exist (Passey and Hugie, 1963). The culms are slender and the leaves are narrow and smooth with the inner surface (upper) grooved and slightly pubescent.

On dry sites under climax conditions the species tends to form pure stands characterized by large bunches almost uniformly spaced. There are between neighboring bunches large areas which are bare or sparingly occupied by small, short-lived, shallow-rooted species such as sandbergs bluegrass (Poa secunda Presl.). Established bunches are relatively long lived and young seedlings are rarely seen in old stands.

Field observations were made on bluebunch wheatgrass plants growing in the native grassland of the Thompson and Nicola valleys in south-central British Columbia. The climate of the area is arid to semi-arid with an average annual precipitation varying from slightly less than $180 \mathrm{~mm}$ in the driest parts to $440 \mathrm{~mm}$ in the wettest parts. Most of the rains come in summer (Tisdale, 1947) in relatively gentle storms with no extensive run-off except on extremely steep or denuded slopes.

Rainwater penetration of the soil under the bunches of the wheatgrass was demonstrated in the field as follows. Trenches about $30 \mathrm{~cm}$ deep were dug on level ground through selected bunches shortly after rain had fallen. The moisture front below the bunches and bare ground could usually be seen (Fig. 1). Penetration patterns were observed under light and heavy grazing at three sites in the Thompson and Nicola valleys.

To confirm the water penetration patterns observed in the field, a trial was conducted in the greenhouse at the University of British Columbia. A wooden box, $45 \mathrm{~cm} \times$ $130 \mathrm{~cm} \times 75 \mathrm{~cm}$ high, was filled with packed garden soil. As the box was filled with soil Bouyoucos moisture blocks (Bouyoucos et al., 1947) were set in three vertical rows at $70,50,25$ and $10 \mathrm{~cm}$ depths (Fig. 2). Two transplanted groups of bluebunch wheatgrass were planted on top of two of the three vertical rows of moisture blocks leaving the middle row of blocks $(\mathrm{C})$ under bare ground as a control. One month was allowed to elapse beforc moisturc readings were started to let the transplanted bunches establish. A mist spray system was constructed to discharge water fairly uniformly over the required area. The uniformity of the mist sprayed at the canopy level of the test plants was tested by replacing the test box with cans and measuring 


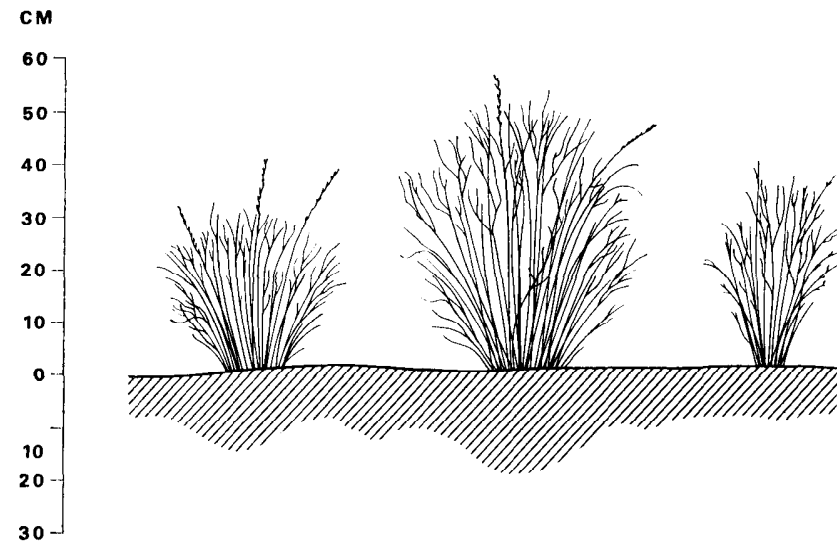

Fig. 1. Moisture penetration in a soil profile after a $29 \mathrm{~mm}$ rainfall. The slope was $6 \% \mathrm{SE}$.

the amount of water trapped in each can after a given time of spraying. The mist-spray system was used to prevent run-off and the tendency to over-saturate the soil along the walls of the box.

Moisture applications and readings started one month after transplanting and continued for three and one-half months. In each test water was applied for one hour. The moisture status of the soil was measured with a wheatstone bridge immediately before and one hour after watering. Watering and moisture readings were undertaken biweekly. After testing four times, one group (B) was clipped to ground level and testing continued a further three times.

Since little lateral movement of water occurs in soil it was assumed that the moisture difference recorded in each row of blocks was due to the downward penetration of water applied.

\section{Results}

Field observations indicated that rainwater penetrated deeper into the soil beneath the bunches of bluebunch wheatgrass than in the patches of bare ground between (Fig. 1). There seemed to be a relation between the size of bunches and the depth of water penetration in roughly sinusoidal moisture-fronts. For example, moisture penetration in the field, following a $29 \mathrm{~mm}$ rain, was $12 \mathrm{~cm}$ under bare ground in contrast to 15,17 , and $20 \mathrm{~cm}$ under plants 30,40 , and $53 \mathrm{~cm}$ tall. The moisture fronts beneath very small bunches of the wheatgrass in soil on the heavily-grazed areas were relatively uniform in depth.

Observations in the greenhouse (Fig. 2) represent the average of four determinations of the levels at which moisture penetration was sensed after one hour of mist spraying when both groups (A and B) were intact and the average of three determinations made after Group B had been clipped. Results obtained in this experiment supported the observation that rainwater penetrates deeper or at least more rapidly beneath the bunches of wheatgrass than in the soil under bare ground. There seemed to be a relationship between the size of the plant

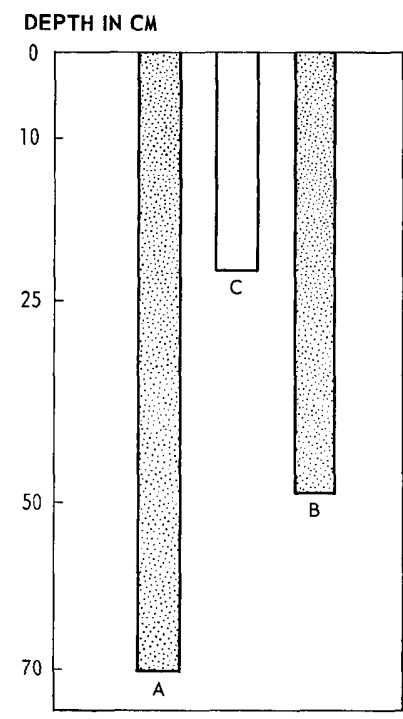

PLANT B INTACT

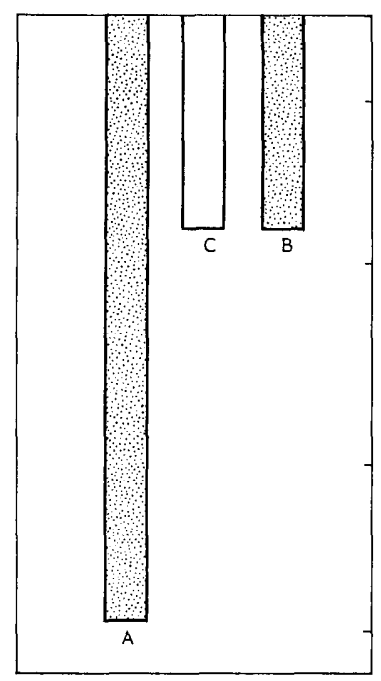

PLANT B CLIPPED
FIg. 2. Depths at which water was detected beneath wheatgrass plants $(A$ and $B$ ) as compared with bare ground $(C)$ between

canopy and the depth to which moisture penetrated. The fact that the clipped bunch gave similar readings to the control suggests that fluctuations in soil moisture penetration are related to the aerial parts of the plant.

\section{Discussion}

Observations made in the field and in the greenhouse support the belief that the deeper penetration of water beneath individuals of caespitose bluebunch wheatgrass is due to a "funnelling" effect of the aerial parts, and that the plant canopy directs light summer rain into the rooting zone of an individual plant. It is also possible that bunches of the wheatgrass impede the movement of rainwater running over bare areas, thus increasing the amount of water which penetrates in the soil around the bunches. However, owing to the nature of the rains in the grasslands studied (Tisdale, 1947), contribution to soil moisture from sheet flow may not be very great.

The ability of the aerial parts of the wheatgrass to intercept and redistribute the incident moisture may have a bearing on the capability of the species to withstand grazing and interspecies competition. It is known that bluebunch wheatgrass easily succumbs to very heavy grazing. In the seeding stage and under heavy grazing the plant does not compete well with annual invaders such as cheatgrass. However, it is clear that annuals rarely invade well developed stands of the wheatgrass (NdawulaSenyimba, 1969). Although he suspected the competition to be for soil nitrates, Harris (1967) admitted that the wheatgrass did better when competing with cheatgrass in places receiving summer 
rains. Whereas reduced nitrates may have a part to play in the annual-perennial grass relationship soil moisture might play a very important role. It is possible that the extensive roots of mature bluebunch wheatgrass (Coupland and Johnson, 1965) utilize all the moisture in the topsoil early in spring. If there are any recharges in the form of rain most of the water received is concentrated beneath the bunches. This would keep patches of bare ground too dry for cheatgrass and other species to colonizc. When the aerial parts of caespitose species are removed annuals share the uniformly distributed moisture in the topsoil and competition is intensified.

Although it cannot be established that the caespitose habit of bluebunch wheatgrass is simply or solely an adaptive morphological feature which relates the thriftiness of the species to a regime of limited soil moisture, the observations strongly suggest that the association is important.

\section{Literature Cited}

Bouyoucos, G. J., AND A. H. Mick. 1947. Improvements in the plaster of paris absorption block electric resistance method for measuring soil moisture under field conditions. Soil Sci., 63:455-465.
Coupland, R. T., And R. E. Johnson. 1965. Rooting characteristics of native grassland species in Saskatchewan. J. Ecol., 53:175-507.

Ellison, L. 1960. Influence of grazing on plant succession of rangelands. Bot. Rev., 26: I-78.

Glover, P. E. 1950. Rainwater penetration in British Somaliland soils. East African Agr. J., 16:26-33.

Glover, P. E., AND M. D. GwYnNe. 1962. Light rainfall and plant survival in East Africa. I. Maize. J. Ecol., 50: 111-118.

Glover, P. E., J. Glover, And M. D. Gwynne. 1962. Light rainfall and plant survival in East Africa. II. Dry grassland vegetation. J. Ecol. 50:199-206.

GwYnne, M. D. 1966. Plant physiology and the future, pp. 59-64. Davis, W. and C. L. Skidmore (ed.) In "Tropical Pastures." Faber and Faber, London.

Harris, G. A. 1967. Some competitive relationships between Agropyron spicatum and Bromus tectorum. Ecol. Monogr., 37:89-111.

Ndawula-Senyimba, M. S. 1969. Fenceline ecology of four grassland sites in the southern interior of British Columbia. M. Sc. Thesis, Univ. of British Columbia, Vancouver. $101 \mathrm{p}$.

Passey, H. B., And V. K. Hugie. 1963. Variations in bluebunch wheatgrass in relation to environment and geographical location. Ecology, 44:158-161.

Tisdale, E. W. 1947. The grasslands of the southern interior of British Columbia. Ecology, 28:346-382. 